\title{
GLOBALIZATION, DE-INDUSTRIALIZATION AND UNDERDEVELOPMENT IN THE THIRD WORLD BEFORE THE MODERN ERA*
}

JEFFREY G. WILLIAMSON

Harvard University

\begin{abstract}
Between 1810 and 1940, a large GDP per capita gap appeared between the industrial core and the poor periphery, the latter producing, increasingly, primary products. Over the same period, the terms of trade facing the periphery underwent a secular boom then bust, peaking in the 1870s or 1890s. These terms of trade trends appear to have been exogenous to the periphery. Additionally, the terms of trade facing the periphery exhibited relatively high volatility. Are these correla-
\end{abstract}

* This paper was delivered as the Figuerola Lecture at Carlos III University, Madrid. (October $6,2005)$. It draws heavily on and extends parts of the Ohlin Lectures given at the Stockholm School of Economics in October 2004 which will appear shortly as Globalization and the Poor Periphery Before the Modern Era (MIT Press 2005a). This work exploits collaborations with Luis Bértola, Chris Blattman, Michael Clemens, David Clingingsmith, John Coatsworth, Yael Hadass, Jason Hwang, Saif Shah Mohammed, Kevin O'Rourke and Alan Taylor, to whom I am very grateful. In addition, it has been improved by help with the data and the argument by Max Corden, Jean-Pierre Dormois, Bob Gregory, Tim Hatton, Elhanan Helpman, Pedro Lains, Peter Lindert, Leandro Prados, \$\$5evket Pamuk, Rod Tyers and, especially, Steve Dowrick and Jason Hwang. In addition, I am happy to acknowledge useful comments from lecture attendees at the Stockholm School of Economics, the Canadian Economic History Network at Queen's University, the University of Melbourne, the Australian National University and the Istanbul EHES meetings. Also, I acknowledge with gratitude the able research assistance of Pedro Glaser, Katherine Johnson and Miray Topay. Finally, I would like to thank Antonio Tena and his colleagues at Carlos III who were such wonderful hosts.

a Department of Economics. Harvard University. Cambridge, MA 02138. jwilliam@fas.harvard.edu. 
tions spurious, or are they causal? This Figuerola Lecture, to be given at Carlos III University (Madrid), argues that they are causal, that secular growth and volatility in the terms of trade had asymmetric effects on core and periphery. On the upswing, the secular rise in its terms of trade had powerful de-industrialization effects in the periphery. Over the full cycle 1810-1940, terms of trade volatility suppressed accumulation and growth in the periphery as well.

\section{Keywords:}

JEL Classification: F10, N10, O10

\section{LAWS OF MOTION: SECULAR TERMS OF TRADE; BOOM AND BUST IN THE PERIPHERY 1810-1940}

This Lecture defines the core as northwest Europe and its overseas settlements, regions where the industrial revolution spread as the $19^{\text {th }}$ century unfolded. The periphery includes the rest -industrially-lagging Europe to the east and south of the core, the Middle East, Africa, Asia and Latin America. The premodern era is defined as the first global century, about 1810 or 1820 to 1913 , plus the anti-global, autarchic interwar, from 1913 to 1940.

The economic impact of the core on the periphery had its source in two forces which arose during the first global century. The first was a world-wide transport revolution that served to integrate world commodity markets (O'Rourke and Williamson 1999, Ch. 3; Mohammed and Williamson 2004; Williamson 2005a, Chs. 2 and 3). It caused a boom in trade between core and periphery, created commodity price convergence for tradable goods between all world markets, and contributed to a rise in every country's external terms of trade, including the periphery, indeed, especially in the periphery. The second force came from the derived demand for industrial intermediates, like cotton, rubber and metals, which soared as manufacturing production led the way in the core. Thus, as core economies raised their industrial output shares, manufacturing output growth raced ahead of GDP growth. Rapid productivity growth lowered the cost and price of manufactures and by so doing generated a soaring derived demand for raw materials in the core. This event was reinforced by accelerating income per capita growth and a high income elasticity of demand for luxury consumption goods, like meat, tea, and coffee. Since industrialization was driven by unbalanced productivity advance favoring manufacturing relative to agriculture and other naturalresource based activities, the relative price of manufactures fell everywhere, especially in the periphery where they were imported. The world transport revolution made it possible for the distant periphery to supply this booming demand for primary products in the core. Both forces produced positive, powerful and sustained 
terms of trade shocks in the periphery, raising the relative price of primary products, and through an epoch which stretched over as much as seventy or eighty years. Factor supply responses in the periphery facilitated these external demand shocks, carried by migrations from labor abundant to labor scarce regions within the periphery and by financial capital flows from the core to tose same regions.

Eventually these two forces abated. The rate of decline in real transport costs along sea lanes slowed down, approaching a late $20^{\text {th }}$ century steady state (Mohammed and Williamson 2004). The rate of growth of manufacturing slowed down in the core as the transition to industrial maturity was completed. As these two forces abated, the resulting slowdown in primary product demand growth was reinforced by resource-saving innovations in the industrial core, induced, in large part, by those high and rising primary product prices during the $19^{\text {th }}$ century terms of trade upswing. Thus, the secular boom faded, eventually turning into a secular bust. Exactly when and where the boom turned to bust depended on export commodity specialization, but the periphery peak ranged between the 1870 s and the 1890s.

This 130-year cycle in the periphery terms of trade is illustrated in Figure 1 by the Latin American experience. The region's terms of trade underwent a steady increase from the 1810 s to the early 1890 s, and the improvement was especially dramatic during the first four decades: the annual rate of increase was 1.3 percent between the half-decade 1815-19 and the half-decade 1890-94, equivalent to

FIGURE 1

1939 GDP PER CAPITA AND TERMS OF TRADE VOLATILITY 1870-1939

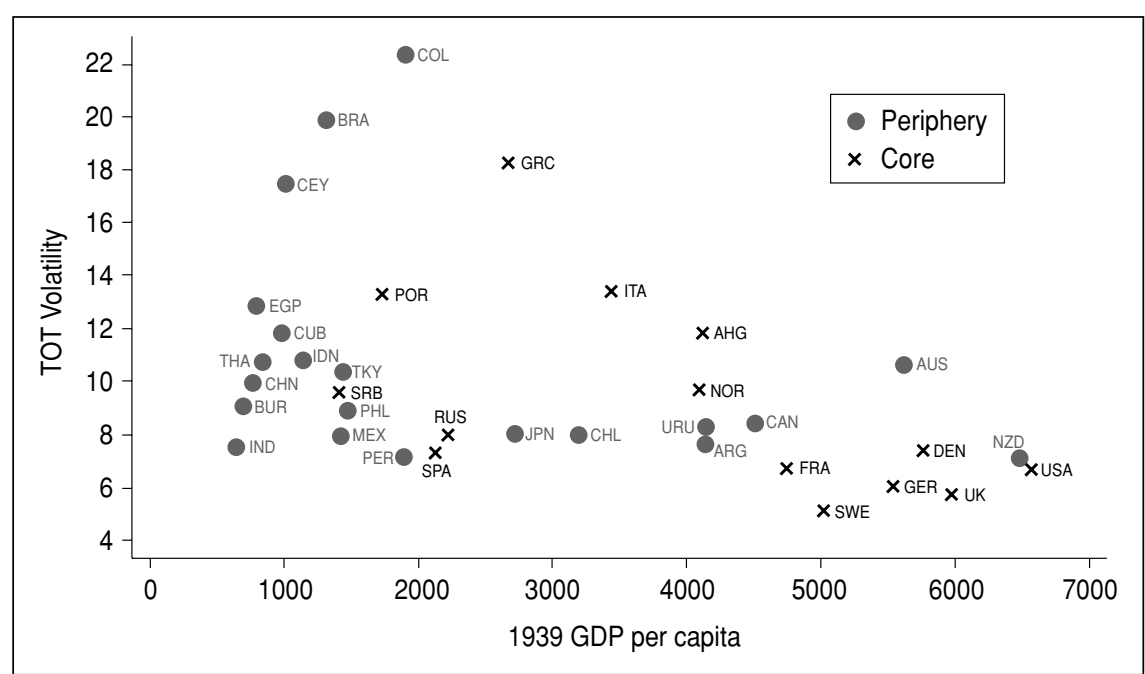


almost a tripling over the 75 years; and the rate between 1815-19 and 1855-59 was even larger, 2.05 percent per annum ${ }^{1}$. Furthermore, that increase is probably understated since it fails to take account of the likely increase in the quality of traded manufactures relative to primary products, estimated in Figure 1 by the dashed line. Based on the estimates underlying Figure 1 reported in Appendix 1, the quality-adjusted terms of trade may have grown at a little more than 2.2 percent per annum between 1815-19 and 1855-59, and at a little more than 1.4 percent per annum between 1815-19 and 1890-94.

Nor was Latin American experience with that secular upswing unusual. Figure 2 documents that the increase was even bigger in Egypt, the Ottoman Empire (Turkey) and Indonesia ${ }^{2}$. What went up then came down with a crash, as the periphery terms of trade fell from the 1870s or 1890s to World War II. As it turns out, the size of that crash has been overstated to the extent that manufactured commodities underwent much faster quality improvement than primary products. Once again, the dashed line in Figure 1 illustrates the point by use of Latin

FIGURE 2

1939 GDP PER CAPITA AND MEAN TERMS OF TRADE GROWTH 1870-1939

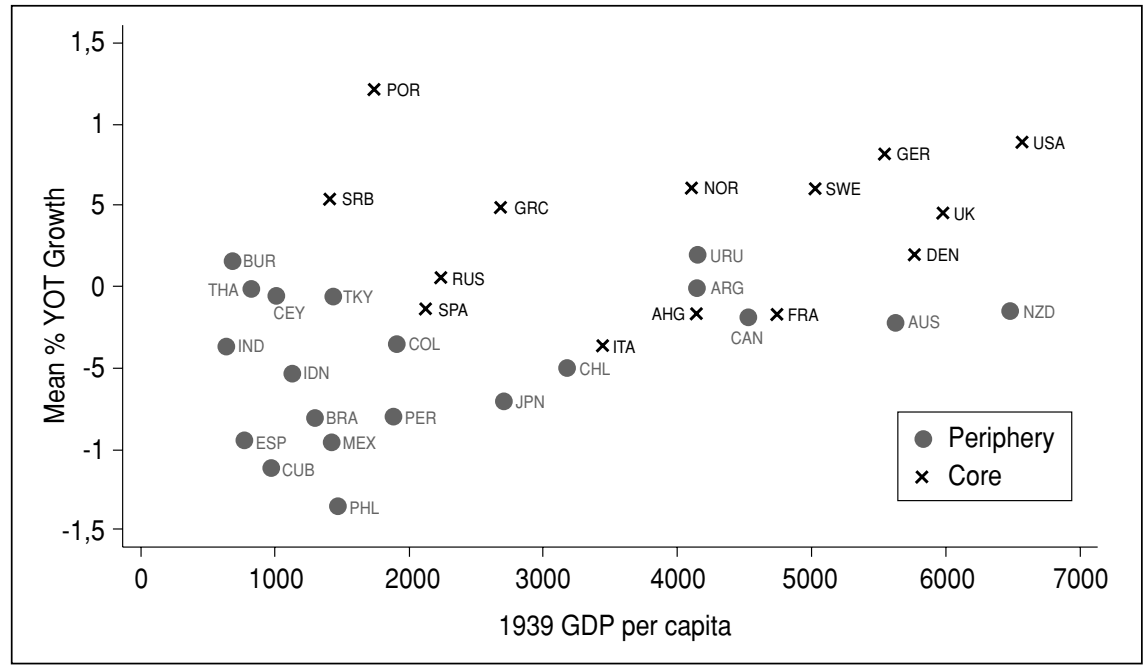

1 There are eight countries underlying the regional series, all of which achieved political independence early in the 130-year terms of trade cycle: Argentina, Brazil, Chile, Colombia, Cuba, Mexico, Peru and Uruguay.

2 The boom was more modest in India (Clingingsmith and Williamson 2004), but it was about the same in the Mideast after 1839 and even more dramatic in Japan after 1858 and the gunboatforced opening-up. 
America: since relative quality gains are typically ignored in estimates of trade trends, and since they favor manufacturing, the quality-adjusted price of manufactures must have fallen by more than the unadjusted series documents (see Appendix 1), enough to have removed some of the terms of trade crash. Exactly how much of the crash would be removed with better quality adjustments is unclear, but this new adjusted series still documents a secular cycle over the 130 years.

Whether during boom or bust, technological advance and human capital accumulation were so modest in the periphery that the living standard gap between it and the core surged to levels that were vastly wider at the end of the cycle than when it started almost a century and a half before. Whether the modest rates of technological advance and human capital accumulation in the periphery were caused at least partly by globalization-induced de-industrialization forces has, of course, been a central issue in growth and development debate since it all started.

Between 1810 and 1940, the periphery obeyed laws of motion that economists delight in exploring. The long run secular boom and bust was generated in response to two of the most profound technological shocks the world had yet seen -in industry and transportation, shocks exogenous to the periphery if not the core. Elsewhere, I have assessed the implications of this secular cycle in terms of trade on income distribution (Williamson 2002, 2005a), and then asked how trade policy responded to it in periphery regions with and without autonomy (Coatsworth and Williamson 2004a, b; Williamson 2005a, b). This Lecture documents these laws of motion in the periphery and assesses their growth consequences.

Finally, consider price volatility around those secular trends. Both Figures 1 and 2 illustrate that the terms of trade facing the poor periphery underwent tremendous instability over the 130 years between 1810 and 1940 and it was primary product price instability doing almost all of the work. What impact did that market volatility have on growth performance in the periphery?

\section{PREBISCH, SINGER AND THE TERMS OF TRADE DEBATE}

Debate over trends in the terms of trade between primary products and manufactures, their causes and their impact has dominated the growth and development literature for almost two centuries. Classical economists claimed that the relative price of primary commodities should improve over time, since land and other natural resources were in inelastic supply while capital and labor were not. As we shall see, the experience over the half century or so before 1870 proved them right: the relative price of manufactures underwent a spectacular decline, while that of primary products soared. In the early 1950s, however, Hans Singer and 
Raúl Prebisch challenged the classical view, asserting that the terms of trade of the primary-product-producing Third World had deteriorated since the late $19^{\text {th }}$ century. Indeed, Prebisch calculated that only 63 percent of the finished manufactures which could be bought with a given quantity of primary products in the $1860 \mathrm{~s}$ could be purchased in the 1930s. Prebisch and Singer also projected that it would continue to deteriorate across the late $20^{\text {th }}$ century as long as the Third World specialized in primary products. It turned out that their projection was not confirmed by late $20^{\text {th }}$ century experience, but my interest lies instead with the 130 years between 1810 and 1940, when the new economic order came to be firmly established.

This important part of the development literature has its shortcomings. While faster technological progress in manufacturing may have caused the price of manufactures to fall relative to primary products over most of the $19^{\text {th }}$ century, and while the $19^{\text {th }}$ century world transport revolution reinforced those forces by lowering import prices and raising export prices in periphery markets, Prebisch and Singer elected to stress the $20^{\text {th }}$ century downside of this secular cycle. Furthermore, while the secular upswing of the terms of trade should have caused de-industrialization - something of which another part of the literature has made much - Prebisch, Singer and their followers ignored this de-industrialization inference. By so doing, they also ignored a symmetric corollary: on the downside, the secular terms of trade deterioration also implied a long run stimulus to import-competing industry in the periphery, what might be called re-industrialization. Prebisch ignored this possibility, and stressed instead the short run economic damage to a periphery so committed to primary product exports.

The main weakness of this literature, however, is that Prebisch, Singer, and many of the contributors to the subsequent literature dealt with the relative price of primary products in world markets, not with the terms of trade facing any given country in the poor periphery. Nor did they assess the economic impact on the poor periphery. Rather, they assumed it.

\section{AGENDA: ASSESSING THE IMPACT OF SECULAR TERMS OF TRADE TRENDS ON THE PRE-MODERN PERIPHERY}

New data confirm that the terms of trade (unadjusted for quality change) fell everywhere in the periphery between the 1870 s or 1890 s and the 1930 s, consistent with the Prebisch-Singer calculation based on commodity prices in core markets rather than (as in this Lecture) on prices in periphery locations. This secular decline in the terms of trade in what we now call the Third World is confirmed by the large 21-country periphery sample underlying Tables 1 and 2: for Asia, the fall from its 1870 s peak to its 1930 s trough was 29 percent; for Latin America, the fall 
from its $1885-1895$ peak to its 1930 s trough was 40 percent $^{3}$. As we have seen, this secular decline was used to support the move towards Third World autarky in the 1940s, 1950s and 1960s, a highly interventionist industrialization strategy which eventually came to be called import substitution industrialization (ISI). While Singer also advocated this anti-global ISI strategy, he noted that if the post1950 relative price of primary products ever did improve, it would reduce industrialization incentives in the periphery (Singer 1950, p. 482). Thus, while a post1950 improvement in the primary product exporter's terms of trade might augment incomes in the short run, a good thing, Singer thought it was also likely to suppress industrialization in the long run, a bad thing. No one seemed to pay much attention to Singer's aside at that time, including Singer himself.

Many modern economists have reached Singer's conclusion, but for different reasons. Some have argued that resources are a «curse» to development, such that while an improvement in the terms of trade facing primary product exporters would increase the value of the resource base being exploited, poor growth would result. Jeffrey Sachs and Andrew Warner (2001) have confirmed the correlation, but economists have not yet agreed on how the «resource curse» works. Some argue that resource abundant poor countries have undeveloped property rights such that terms of trade booms get translated into capital flight (a transfer of rents for safekeeping in rich countries: Tornell and Velasco 1992). Others make the case for growth-suppressing rent-seeking (Krueger 1974; Murphy, Shleifer and Vishny 1993; Baland and Francois 2000) and to growth-distorting government policy (Tornell and Lane 1999). Still others favor crowding-out and Dutch disease, a position this Lecture also favors. Initiated first by Bob Gregory (1976), Max Corden (1981, 1984) and Corden and Peter Neary (1982), a huge literature has developed over the past twenty-five years which has examined how manufacturing in modern economies has been affected by the discovery of tradable natural resources or by an increase in their price. The name «Dutch disease» is taken from the impact of natural gas price increases on the Dutch economy in the 1970s. The most extensive applications, however, have been to Third World economies which specialize in primary products. There have been far fewer applications of deindustrialization and Dutch disease models to development in the periphery over the 120 or 130 years before the modern late $20^{\text {th }}$ century experience. Whichever view one supports, the Sachs-Warner correlation has also been found in the more distant past: my earlier work with Yael Hadass (Hadass and Williamson 2003) found that for a small sample of primary product exporters between 1870 and World War I poor growth did ensue following the terms of trade mprovement, lending some limited support to resource curse theories.

3 There are ten countries in our Asia sample: Burma, Ceylon, China, Egypt, Indonesia, Japan, the Philippines, Siam and Turkey (the Ottoman Empire). 
Others have argued for the more benign classical view where an increase in the price of the primary product export raises the expected rate of return on investment in that sector, thus augmenting accumulation and growth economy-wide. Using a cross-country panel of 40 countries from 1970 to 1991, Enrique Mendoza (1997) did indeed find that an increase in the growth rate of the terms of trade by 1 percent raised the growth rate of consumption by 0.2 percent, although most of the developing countries in his sample were exporting labor-intensive manufactures by the end of the period, not primary products ${ }^{4}$. Still, Michael Bleaney and David Greenaway (2001) used Mendoza's model to analyze sub-Saharan Africa between 1980 and 1995, where primary product exports still dominated (at least up to the early 1990s: see below), finding that both GDP per capita growth and investment increased as the terms of trade improved.

The Prebisch-Singer primary-product-terms-of-trade-deterioration thesis has not survived the half century since they wrote: fifty years later, we now think that structural breaks, serially correlated residuals and unit roots may explain the $20^{\text {th }}$ century (unadjusted) terms of trade patterns we see, or that proper quality-adjustment might further erase any deterioration (Lipsey 1994). Thus, Enzo Grilli and Maw Cheng Yang (1988) analyzed $20^{\text {th }}$ century commodity price data and found evidence of periodic structural breaks, but no trend. Bleaney and Greenaway (1993) contested this finding, but were able to document only a modest downward trend. Furthermore, and to repeat, most of the periphery was little damaged by this modest secular deterioration since by the 1990s the majority had shifted out of primary-product exports and into labor-intensive manufacture exports. Thus, from today's vantage point, the Prebisch-Singer secular deterioration hypothesis, and its implied negative impact, can be rejected. It is not clear, however, that it should be rejected from the vantage point of 1950 when Singer and Prebisch were looking backward to the 1870s. Nor has the modern literature yet measured the impact that the terms of trade secular deterioration had on long run GDP per capita growth in the periphery. If we had the answer, we could then use it to help assess the data-scarce terms of trade boom period before the $1870 \mathrm{~s}$, when the great divergence between center and periphery development levels appeared.

The jury is still out. What we need is a larger sample of periphery countries, and we need it for the period that motivated the Prebisch-Singer debate in the first place. It has proven difficult to construct the necessary data base for the pre-1870 epoch, but we have done it for the post-1870 epoch. So, when the terms of trade of primary products deteriorated between 1870 and 1940, what was its economic impact on the periphery? The answer will hinge on two additional questions:

\footnotetext{
${ }^{4}$ Industrial manufactures have been a rapidly rising share of Third World output and exports, as we shall see below.
} 
When and where in the periphery did the terms of trade deteriorate, and by how much? When and where it did deteriorate, and thus when and where the relative price of import competing manufactures rose, was the positive long run GDP growth stimulated by induced industrialization enough to overcome the negative short run effect?

\section{AGENDA: ASSESSING THE IMPACT OF TERMS OF TRADE VOLATILITY ON THE PRE-MEDERN PERIPHERY}

Until the last three decades or so, most countries in the periphery specialized in the export of just a handful of commodities (Table 1, cols. 3 and 7). In the 1920s, for example, the top two exports were 82 percent of all exports from the average Third World country, while they were 12 percent in the industrial core even two decades earlier. Furthermore, some of these commodities had prices which were a lot more volatile than others, and those countries with the greater volatility grew more slowly relative to the industrial leaders and relative to other primary product exporters. Figure 3 charts income per head in 1939 against terms of trade volatility for 35 countries between 1870 and $1939^{5}$. Volatility is measured as the standard deviation of departures from a slow-moving trend ${ }^{6}$. The figure clearly depicts a negative correlation between terms of trade volatility and subsequent level of development, not just in the total sample but also within the subset of primary product-specialized countries in the periphery. Figure 4 charts 1939 income per head against the secular trend in the terms of trade. Within both the periphery and the core, we see a positive correlation between growth in the terms of trade and subsequent level of development. As noted above, these correlations are reminiscent of what Carlos Diaz-Alejandro (1984) called the commodity lottery. He argued that each country's exportable resources were determined in large part by geography (plus the previous century's experience with global market integration), and that differences in subsequent economic development were a consequence of the economic, political and institutional attributes of each commodity.

So far, this Lecture has focused on secular terms of trade movements and their implications for industrialization and de-industrialization, but could it be that exogenous price volatility of each primary product also mattered by generating internal instability, reduced investment, and diminished economic growth? Observers regularly point to terms of trade shocks as a key source of macroeconomic insta-

5 The World War I years are omitted. The 35 countries in the Blattman-Hwang-Williamson sample are listed in Table 1.

${ }^{6}$ This trend was calculated using a Hodrick-Prescott filter. See the discussion in the Appendix. 
FIGURE 3

LATIN AMERICAN TERMS OF TRADE 1811-1939

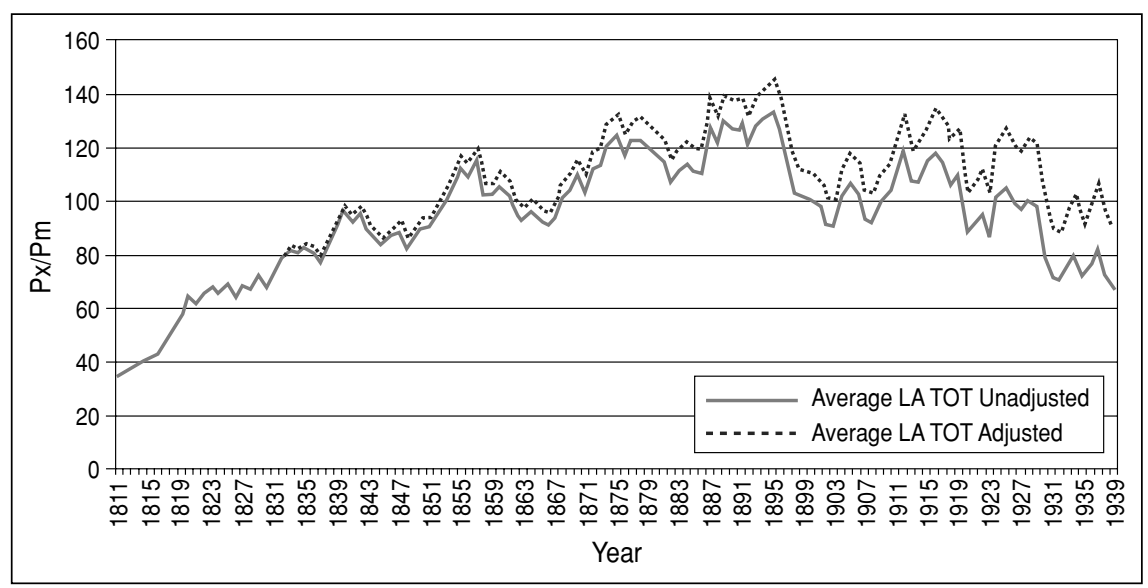

bility in commodity-specialized countries, but they pay far less attention to the long run growth implications of such instability ${ }^{7}$. Most theories stress the investment channel in looking for connections between terms of trade instability and growth. Indeed, the development literature offers an abundance of microeconomic evidence linking income volatility to lower investment in both physical and human capital. Households imperfectly protected from risk change their incomegenerating activities in the face of income volatility, diversifying towards low-risk alternatives with lower average returns (Dercon 2004; Fafchamps 2004), as well as to lower levels of investment (Rosenweig and Wolpin 1993). Furthermore, severe cuts in health and education follow negative shocks to household income in poor countries - cuts that disproportionately affect children and hence long term human capital accumulation (Jensen 2000; Jacoby and Skoufias 1997; Frankenburg et al. 1999; Thomas et al. 2004).

Poor households find it difficult to smooth their expenditures in the face of shocks because they are rationed in credit and insurance markets, so they lower investment and take fewer risks with what remains. Poor firms find it difficult to smooth net returns on their assets, so they lower investment and take fewer risks with what remains. Perhaps most importantly, poor governments whose revenue sources are mainly volatile customs duties (Coatsworth and Williamson 2004b; Williamson 2005b) and which also find it difficult to borrow at cheap rates locally

7 For important exceptions, see Mendoza (1997), Deaton and Miller (1996), Kose and Reizman (2001), Bleaney and Greenway (2001) and Hadass and Williamson (2003). 
FIGURE 4

TERMS OF TRADE COMPARISONS

ON THE UP-SIDE: THE PERIPHERY 1820-1860. 1828=100

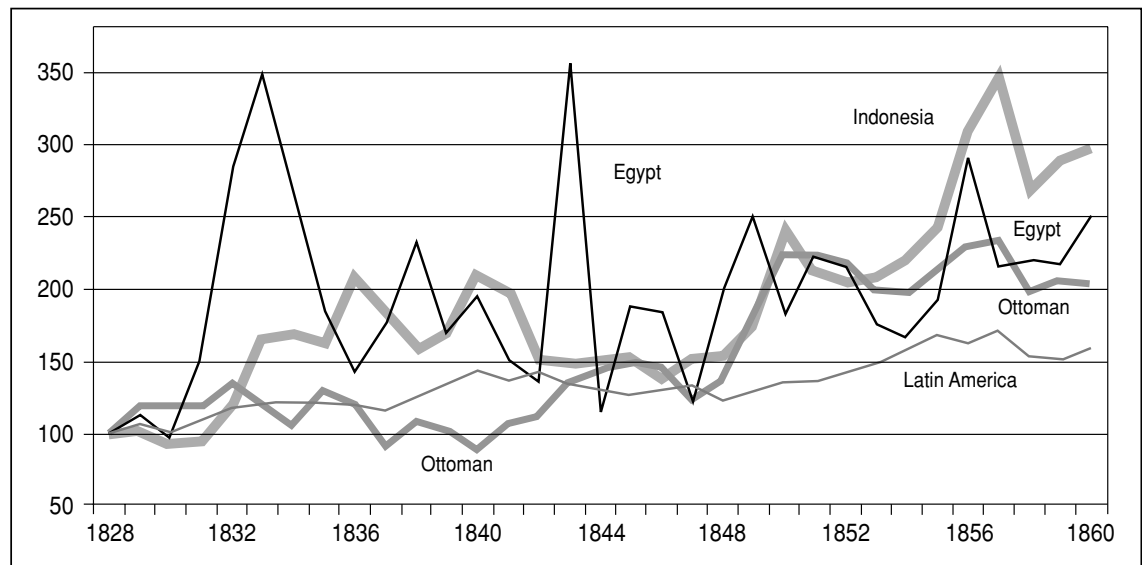

and internationally, cannot, without serious difficulty, smooth public investment in and expenditure on long run infrastructure and education in the face of terms of trade shocks ${ }^{8}$. Lower public investment ensues, and growth rates fall. Garey and Valerie Ramey (1995) examined the macroeconomic volatility and growth correlation using data from 92 developing and developed economies between 1962 and 1985. They found government spending and macroeconomic volatility to be inversely related, and that countries with higher volatility had lower mean growth.

In short, theory informs us that higher volatility in the terms of trade should reduce investment and growth in the presence of risk aversion. In addition, the less-risky investment that does take place will also be low-return. Modern evidence seems to be consistent with the theory. What is true of the modern era was probably even more true of the 1870-1940 period when undeveloped financial institutions and a limited tax base made it even harder for poor households, poor firms and poor governments to smooth expenditures. And, in turn, what was true of 1870-1940 must have been even more true of 1810-1870, and for the same reasons.

${ }^{8}$ While greater volatility increases the need for international borrowing to help smooth domestic consumption, Cat\$ $\$ 40$ and Kapur (2004) have shown recently that volatility constrained the ability to borrow between 1970 and 2001. It seems likely that the same was true between 1870 and 1901 , a century earlier. 


\section{THE JURY IS IN: THE IMPACT OF SECULAR TREND AND VOLATILITY IN PERIPHERY TERMS OF TRADE 1870-1939}

There are 35 countries in the historical sample that Chris Blattman, Jason Hwang and I (Blattman, Hwang and Williamson 2004) used recently to explore these issues: 14 in the core and 21 in the periphery, although the results are robust to every plausible core-periphery allocation explored ${ }^{9}$. Table 1 lists the 35 countries by GDP per capita, the dominance of primary products in exports, export

TABLE 1

PROFILE OF THE CORE AND PERIPHERY 1870-1939

\begin{tabular}{|c|c|c|c|c|c|c|c|c|}
\hline & \multicolumn{4}{|c|}{$1870-1889$} & \multicolumn{4}{|c|}{ 1920-1939 } \\
\hline & $\begin{array}{c}\text { GDP } \\
\text { per } \\
\text { capita }\end{array}$ & $\begin{array}{c}\text { Primary } \\
\text { Products } \\
\text { as \% of } \\
\text { Export }\end{array}$ & $\begin{array}{c}\text { Top 2 } \\
\text { Exports } \\
\text { as \% of } \\
\text { Top } 5 \\
\text { Export }\end{array}$ & $\begin{array}{c}\text { Exports } \\
\text { as \% of } \\
\text { GDP }\end{array}$ & $\begin{array}{c}\text { GDP } \\
\text { per } \\
\text { capita }\end{array}$ & $\begin{array}{c}\text { Primary } \\
\text { Products } \\
\text { as \% of } \\
\text { Exports }\end{array}$ & $\begin{array}{c}\text { Top 2 } \\
\text { Exports } \\
\text { as \% of } \\
\text { Top } 5 \\
\text { Exports }\end{array}$ & $\begin{array}{c}\text { Exports } \\
\text { as \% of } \\
\text { GDP }\end{array}$ \\
\hline \multicolumn{9}{|c|}{$\begin{array}{l}\text { PERIPHERY } \\
\text { European "Frontier" Offshoots }\end{array}$} \\
\hline \multirow{4}{*}{$\begin{array}{l}\text { Australia........... } \\
\text { Canada ............ } \\
\text { New Zealand ... }\end{array}$} & 4.442 & $97 \%$ & $98 \%$ & $15 \%$ & 5.268 & $96 \%$ & $76 \%$ & $15 \%$ \\
\hline & 1.822 & $95 \%$ & $96 \%$ & $12 \%$ & 3.993 & $74 \%$ & $51 \%$ & $19 \%$ \\
\hline & 3.668 & $99 \%$ & $100 \%$ & $16 \%$ & 5.232 & $99 \%$ & $69 \%$ & $25 \%$ \\
\hline & 3.311 & $97 \%$ & $98 \%$ & $15 \%$ & 4.831 & $89 \%$ & $65 \%$ & $20 \%$ \\
\hline \multicolumn{9}{|l|}{ Latin America } \\
\hline Argentina.. & 1.676 & $100 \%$ & $87 \%$ & $15 \%$ & 3.912 & $99 \%$ & $47 \%$ & $14 \%$ \\
\hline Brazil.. & 755 & $100 \%$ & $86 \%$ & $17 \%$ & 1.087 & $100 \%$ & $92 \%$ & $9 \%$ \\
\hline Chile................. & 1.185 & $99 \%$ & $100 \%$ & $22 \%$ & 2.800 & $100 \%$ & $100 \%$ & $12 \%$ \\
\hline Colombia.......... & 1.113 & $99 \%$ & $100 \%$ & $4 \%$ & 1.486 & $99 \%$ & $100 \%$ & $7 \%$ \\
\hline Cuba ........... & 1.647 & $80 \%$ & $a$ & $49 \%$ & 1.440 & $96 \%$ & $100 \%$ & $41 \%$ \\
\hline Mexico ............. & 835 & $100 \%$ & $99 \%$ & $4 \%$ & 1.463 & $99 \%$ & $62 \%$ & $7 \%$ \\
\hline Peru .................. & 497 & $99 \%$ & $74 \%$ & $24 \%$ & 1.451 & $100 \%$ & $67 \%$ & $12 \%$ \\
\hline \multirow[t]{2}{*}{ Uruguay ........... } & 1.676 & $100 \%$ & $74 \%$ & $22 \%$ & 3.912 & $100 \%$ & $85 \%$ & $18 \%$ \\
\hline & 1.173 & $97 \%$ & $89 \%$ & $20 \%$ & 2.194 & $99 \%$ & $82 \%$ & $15 \%$ \\
\hline \multicolumn{9}{|c|}{ Asia \& the Middle East } \\
\hline Burma... & 628 & $91 \%$ & $100 \%$ & $14 \%$ & 751 & $98 \%$ & $83 \%$ & $45 \%$ \\
\hline Ceylon .............. & 730 & $98 \%$ & $100 \%$ & $11 \%$ & 1.114 & $98 \%$ & $100 \%$ & $15 \%$ \\
\hline China ................. & 565 & $98 \%$ & $73 \%$ & $1 \%$ & 769 & $85 \%$ & $43 \%$ & $1 \%$ \\
\hline Egypt ................. & 369 & $93 \%$ & $100 \%$ & $29 \%$ & 650 & $97 \%$ & $100 \%$ & $18 \%$ \\
\hline
\end{tabular}

9 This sample covered about 90 percent of world population in 1900, and an even bigger share of world GDP and trade. See Table 1 for a listing for the nine European core countries, their three rich overseas offshoots, 21 poor periphery countries, and two on the margin. 
GLOBALIZATION, DE-INDUSTRIALIZATION AND UNDERDEVELOPMENT IN THE THIRD...

TABLE 1 (Cont.)

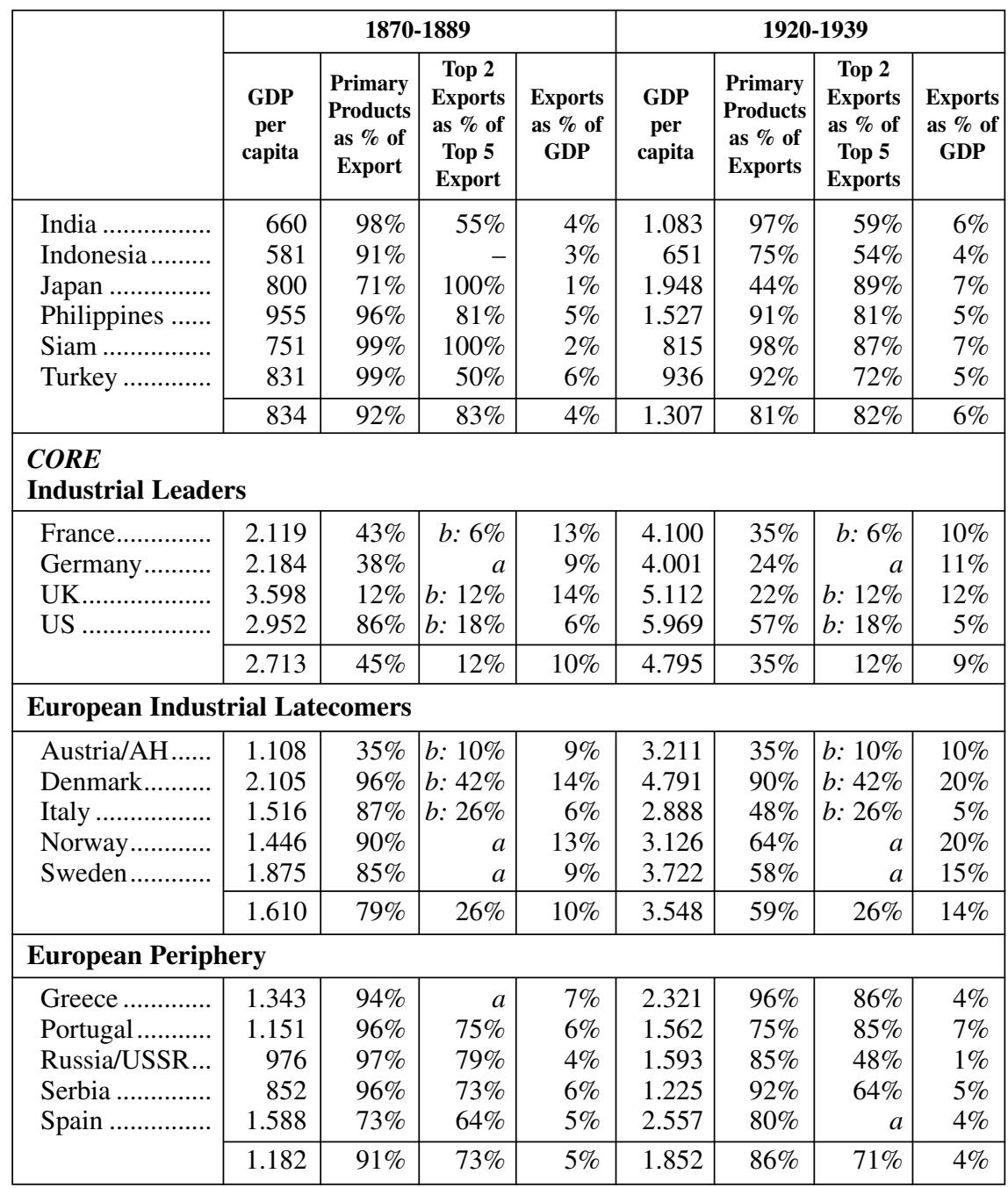

Sources: For all but note b, Blattman, Hwang and Williamson (2004), Table 1.

$a$ : No data available for this period. b: Top export share in 1900, Hanson (1980: 39).

concentration and export shares in GDP. The impact of secular change and volatility in the terms of trade is presented in Table 2. Results are displayed for the full seven decades (1870-1939), although it has been shown that the two sub-periods - the first global century from 1870 to 1909 and the interwar autarchic disaster 
from 1920 to 1939 - exhibit the same behavior ${ }^{10}$. The World War I decade is omitted throughout.

The results are reported separately for the core and periphery, making it possible to test for the presence of asymmetry between them. Asymmetry is predicted by the following reasoning. Consider secular impact first. To the extent that the periphery specializes in primary products, and to the extent that industry is a carrier of development, then positive price shocks reinforce specialization in the periphery and cause de-industrialization there, offsetting the short run income and static specialization gains yielded by the terms of trade improvement. However, there is no such offset in the core, but rather there is a reinforcement, since specialization in industrial products is strengthened there by an improvement in the terms of trade. Thus, the prediction is that while a secular terms of trade improvement unambiguously raises growth rates in the industrial core, it does not do so in the periphery. I expect the same asymmetry with respect to terms of trade volatility to the extent that «insurance» is cheaper and more widely available in the core. For example, to the extent that core governments have a much wider range of tax sources, their tax revenues should be more stable in response to terms of trade shocks than should be true of periphery governments which rely instead on tariffs and export taxes. The induced macro-instability should have suppressed accumulation in risk adverse periphery countries: poor governments should have invested less in their infrastructure; poor parents should have invested less in the education of themselves and their children; and poor firms should have invested less in new products and new technologies.

To see whether the terms of trade impact was contingent upon the level of export dependence, our previous collaborative work added a term interacting TOT Trend Growth with export share of GDP. The motivation, of course, was that more export-oriented countries seemed likely to respond more forcefully to external shocks. Export shares were taken from the first year of the decade to avoid problems of endogeneity. In any case, the key results were not greatly influenced by this complication, so Table 2 ignores it in order to make things simple here. Finally, Table 2 also reports estimates with and without control variables representing other long run growth «fundamentals» like (log) initial GDP per capita, lagged population growth and the prevalence of schooling. I favor the results with the controls, so will focus on cols. (2), (4), (6) and (8) in what follows.

The top half of Table 2 reports the regression estimates and hypothesis testing for the terms of trade effects. The bottom half reports the quantitative and econo-

10 The periphery consists of 21 countries. Data exist for every country and every decade, except for one country-decade observation, yielding a sample of $125(=21 \times 6-1)$. There are a few more missing observations from the interwar core, leaving 79 observations instead of the $84(=14 \times 6)$ that would be available in a complete dataset. The full data base is described in Blattman, Hwang, and Williamson (2004). 
GLOBALIZATION, DE-INDUSTRIALIZATION AND UNDERDEVELOPMENT IN THE THIRD...

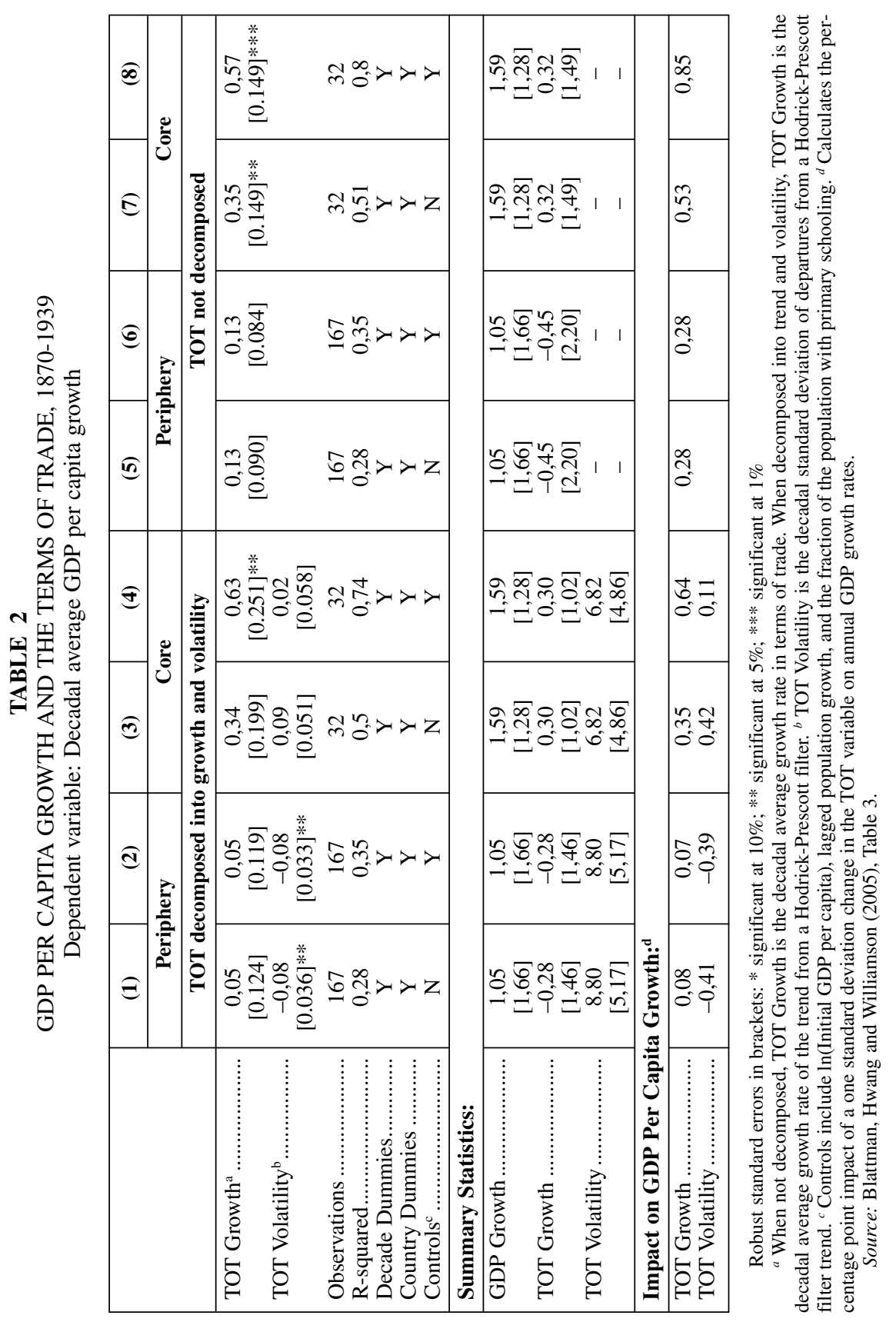


mic importance of these terms of trade effects. Thus, the bottom half shows the sample means and standard deviations of the independent variables. Their marginal impact is, of course, measured as the predicted change in output growth from a marginal increase in the independent variable. That is, for both terms of trade trend growth and volatility, the marginal impact is just the reported coefficient estimate. However, the last rows of Table 2 show the predicted change in output from a one-standard-deviation increase in either the growth or volatility of the terms of trade, thus showing how a plausible change in either independent variable would have influenced output. The word «plausible» applies to the years covered by the sample, namely 1870-1939. The change may not be quite so plausible when applied outside the sample, namely 1810-1870, when the terms of trade for primary products soared. We will return to this issue below.

Columns (2) and (4) of Table 2 strongly support the asymmetry hypothesis. Greater secular improvements in the terms of trade were significantly and positively associated with long run output growth in the core, but not in the periphery. While the core benefited greatly from a small but positive secular improvement in its terms of trade, positive improvement in the periphery — when it made a rare appearance- did not translate in to more growth, but less. Greater volatility had a significant negative influence on income growth in the periphery, but not in the core.

Although not reported here, the main findings continue to receive strong support for the pre-World War I years. Secular improvements in the terms of trade raised long run output growth in the core, but not in the periphery, while greater volatility diminished growth in the periphery, but not in the core. The interwar years involve a much smaller sample and, as a result, the standard errors are large and the statistical significance is low, but the point estimates are generally consistent with those found for the pre-war era. It seems reasonable, therefore, to conclude that the same forces were at work both before and after the war. Still, strong support for the asymmetry hypothesis is especially welcome for the 1870-1910 years, since that result will reinforce the plausibility of exploring its implications for the immediately preceding $1810-1870$ period.

The economic effects were very large. A one-standard-deviation increase in TOT Trend Growth was associated with a 0.64 percentage point increase in the average annual growth rate of per capita GDP in the core - a big number given that the average annual per capita growth rate in the core was just 1.59 percent. The economic effect of TOT Volatility in the periphery was even larger: a onestandard-deviation increase lowered output growth by nearly 0.39 percentage points, a big number given that the average per capita growth rate in the periphery was just 1.05 percent per annum. To repeat, these magnitudes are very similar with and without the export share interaction term.

More generally, these magnitudes suggest that terms of trade shocks were an important force behind the substantial divergence in income levels between core 
and periphery, a core-periphery gap that started to open up so dramatically in the early $19^{\text {th }}$ century (Pritchett 1997). The gap in per capita income per annum growth rates between core and periphery in our sample was 0.54 percentage points (1.59-1.05). If the periphery had experienced the same terms of trade volatility as the core, price volatility would have been reduced by $1.98(\delta=[8.80-6.82]=+1.98)$, adding 0.16 percentage points to average GDP per capita growth rates there $([\beta=-$ $0.08] \times[\delta=-1.98]=+0.16)$. This alone erases about a third of the output per capita growth gap $(0.16 / .54=0.3)$. If, in addition, the core had experienced the same secular deterioration in its terms of trade that the periphery did $(-0.28)$, instead of the observed positive 0.3 percent per annum growth rate $(\delta=[-0.28-(+) 0.30]=-$ $0.58)$, this would have reduced output growth there by 0.37 percentage points $([\beta=+0.63] \times[\delta=-0.58]=-0.37)$. Combined, these two counterfactuals would have eliminated nearly the entire gap in growth rates between core and periphery $(0.16+0.37=0.53)$. These results are robust to the use of alternative periphery allocations, terms of trade growth and volatility measures, and time period ${ }^{11}$. However, they are not robust to assumptions about estimated quality change in traded manufactures. Recall that Lipsey $(1964$, p. 19) concluded that quality improvement in traded manufactured goods was too slow to influence short run terms of trade instability, so any estimated quality adjustment should not influence our volatility inferences. It did, however, influence secular change in the terms of trade, as we see in Figure 1: while the unadjusted terms of trade in the core rose by 0.30 percent per annum between 1870 and 1939, according to these estimates the quality-adjusted terms of trade did not rise at all (0.30-0.33=-003). Thus, secular movements in the terms of trade may have contributed nothing to the growth gap between core and periphery after 1870 . Before 1870 is another matter, however, since the unadjusted terms of trade boom was much bigger and quality improvements in traded manufactures were much smaller.

What accounts for the asymmetric effects of terms of trade growth between core and periphery over the seven decades 1870 to 1940 ? The core benefited from a secular increase in its terms of trade since it reinforced comparative advantage there, helped stimulate industrialization, thus augmenting growth-induced spillovers. That is, dynamic effects reinforced static effects. The fact that the periphery, in contrast, did not benefit when the terms of trade rose over the long term, or suffer when it fell, appears to support de-industrialization and resource curse effects. That is, dynamic losses offset static gains. In my opinion, the place to look for the source of dynamic asymmetry between secular impact on core and periphery is de-industrialization.

But what accounts for the asymmetric effects of terms of trade volatility between core and periphery after 1870? To illustrate the impact of terms of trade

${ }^{11}$ See the appendix tables in Blattman, Hwang and Williamson (2004). 
volatility in the periphery, consider that per capita income in Canada grew faster than in Indonesia by about 1 percent per annum. The difference in terms of trade volatility between the two countries was just under one half of one standard deviation. The estimates in Table 2 imply that if, through better luck in the commodity lottery, Indonesia had experienced Canada's smaller terms of trade volatility, it would have grown faster by about 0.3 percentage points, reducing the growth rate gap between them by a third. So, exactly what kind of insurance did the industrial core take out that allowed it to escape the damaging consequences of terms of trade instability, insurance that was not, apparently, available to primary product exporters in the periphery? Did the industrial core simply have better-developed institutions, policies and tax mechanisms by which to insure against adverse shocks? I do not offer any answers here in this Lecture, but the questions certainly suggest an exciting agenda for the future.

\section{VOLATILITY, ACCUMULATION INFERENCES AND BACKWARD PROJECTIONS TO 1815}

Although the secular rise in the periphery's terms of trade up to the 1870 s or 1890s was certainly spectacular, the empirical results for 1870-1939 suggest that they probably made no positive contribution to economic growth there. While much more needs to be done to identify the channels of this impact, the most promising hypothesis is that de-industrialization was the long run offset to short run income or medium term specialization gains. Furthermore, to the extent that industrialization had a positive impact on human and physical capital accumulation, this is one plausible channel through which de-industrialization contributed to diminished growth. We will pursue the connection below.

But assuming for the moment that the secular boom in the terms of trade had no net long term positive impact in the poor periphery, what about the negative impact of export price and terms of trade volatility? Once again, while the data are not adequate to estimate the impact of pre-1870 volatility, we can use the 18701939 parameter estimates to project that impact backwards given the pre-1870 terms of trade experience. One only has to assume that the pre-1870 forces at work were equal to or greater than those estimated for post-1870, an assumption which seems plausible to me. Thus, I use the same Hodrick-Prescott filter to remove the trend from the pre-1870 terms of trade reported for various periphery regions, leaving the volatility portion for analysis ${ }^{12}$.

12 I am grateful to Jason Hwang for decomposing growth and volatility from my new 18101870 terms of trade series. We use the same procedure for the pre-1870 data as that which was applied to the post-1870 data. 
I have collected pre-1870 terms of trade time series for the following seven regions in the poor periphery: Egypt, India, Indonesia, Latin America, the Mideast, Spain and the Ottoman Empire (Turkey) ${ }^{13}$. What follows immediately below are volatility statistics measured by the standard deviation from trend (see Appendix), where, of course, bigger standard deviations imply greater terms of trade volatility:

\begin{tabular}{|c|c|}
\hline Indonesia 1820-1870 ............................ & 3.81 \\
\hline Latin America 1820-1870. & 5.18 \\
\hline Spain $1815-1870 \ldots \ldots \ldots \ldots . . . .$. & 7.95 \\
\hline Turkey $1815-1870 \ldots \ldots$. & 9.24 \\
\hline Mideast $1839-1870 \ldots . .$. & 19.82 \\
\hline India $1815-1870 \ldots \ldots \ldots$ & 23.09 \\
\hline Egypt $1820-1870 \ldots \ldots .$. & 31.45 \\
\hline $1815-1870$ average.... & 14.39 \\
\hline $1870-1939$ average... & 8.80 \\
\hline JK $1815-1870$ & 0.45 \\
\hline
\end{tabular}

The terms of trade volatility in the poor periphery was much greater before 1870 than after —more than half again as large- implying that it played an even bigger role in contributing to the coreperiphery growth rate gap before 1870 . If the GDP per capita growth gap between core and periphery 1815-1870 was anything like it was 1870-1939, terms of trade volatility must have explained two thirds of the gap. To be more confident about this inference, we need to compare periphery with core. Recall from Table 2 that the periphery-core volatility difference was +1.98 between 1870 and 1939. If we take the UK to represent the core before 1870 , then its relative terms of trade stability (6.45 for the UK before 1870 versus 8.80 for the core after 1870) implies an even bigger volatility difference between core and periphery before 1870 than after, compared to what the raw volatility statistics for the periphery suggest. Thus, if the periphery had experienced the same terms of trade volatility as did the United Kingdom, volatility there would have been reduced by $7.91(\delta=[14.39-6.45]=+7.94)$, adding a huge 0.63 percentage points to average GDP per capita growth rates there $([\beta=-0.08] \times[\delta=-7.94]=+0.63)$.

While the volatility differences before and after 1870 are large, the differences between the periphery regions are even larger. Indonesia and Latin America had relatively stable terms of trade (compared to the periphery average and to the United Kingdom), so poor growth performance cannot be laid at the feet of terms of trade volatility in those regions. Egypt, India and the Mideast, on the other

13 The series for Japan starts too late, 1858, for the volatility analysis. There are other time series which I hope to add in the near future, including Portugal 1842-1870 and Italy 1815-1870 from the south European periphery. New potential candidates from Asia might be China and the Philippines, as well as some from the east European periphery. 
hand, had immense volatility, and their growth must have suffered greatly as a consequence. Spain and Turkey lay somewhere in between with volatility figures (7.95 and 9.24) close to the post-1870 periphery average (8.80), but still higher than the pre-1870 United Kingdom figure (6.45) and the post-1870 core average (6.82).

Terms of trade volatility in the periphery suppressed long run growth considerably there, helping contribute to the rising GDP per capita gap between it and the core. As we suggested above, it seems likely that the key channel of impact was through suppressed accumulation rates. Indeed, when one channel of terms of trade impact is investigated - the flow of investment funds from Britain - it appears that capital inflows 1870-1939 were negatively influenced by terms of trade volatility in the periphery, but not in the core (Blattman, Hwang and Williamson 2004).

Are the magnitudes driving the econometric result in Table 2 plausible? That is, how much would accumulation rates and investment rates have to have fallen in the poor periphery to account for the estimated impact of terms of trade volatility on growth? The econometric estimates in Table 2 argue that terms of trade volatility 1870-1939 lowered per capita GDP growth in the periphery by 0.7 percentage points $(-0.7=8.8 \mathrm{x}-0.08)$ or by almost 0.2 percentage points compared with the core $(-0.16=[8.80-6.82] \mathrm{x}-0.08)$. Assuming a Cobb-Douglas production function, the capital-output ratio $(\mathrm{K} / \mathrm{Y})$ to be constant at 3, capital's share $(\alpha)$ to be 0.3 , and letting $\mathrm{I}=\delta \mathrm{K}$, the change in the rate of per capita GDP growth in percentage points $\left(\Delta y^{*}\right)$ is

or

$$
\begin{array}{r}
\Delta \mathrm{y}^{*}=\alpha \Delta(\mathrm{I} / \mathrm{K})=\alpha \Delta([\mathrm{I} / \mathrm{Y}][\mathrm{Y} / \mathrm{K}])=[\alpha /(\mathrm{K} / \mathrm{Y})] \Delta[\mathrm{I} / \mathrm{Y}] \\
\Delta[\mathrm{I} / \mathrm{Y}]=\Delta \mathrm{y}^{*} / 0.1 \quad=0.3 / 3 \Delta[\mathrm{I} / \mathrm{Y}]=0.1 \Delta[\mathrm{I} / \mathrm{Y}]
\end{array}
$$

This implies that the net investment share need only have fallen by about 2 percentage points $(-.16 / 0.1=-1.6)$ to reproduce the econometric estimate of terms of trade volatility on growth, that is from 7 to 5 percent. This seems like a plausible range to me, and it is close to a third of W. Arthur Lewis's famous dictum that the key to development in the poor periphery was to increase the net investment rate there from five to twelve percent (Lewis 1954, p. 155) ${ }^{14}$. Two thirds for fundamentals like culture, geography and institutions, and one third for terms of trade volatility seems about right to me, although these figures probably reversed their relative magnitudes before 1870 .

${ }^{14}$ Recall that Sir Arthur made that statement in 1954 long before Third World investment rates two or three times that 12 percent became so common. His observation was based on $19^{\text {th }}$ century (slow population growth) experience, and that is what we are trying to explain here as well. 


\section{DOES THE PAST INFORM THE FUTURE?}

Should we expect the same volatility and secular growth effects for the post1970 decades? I doubt it: the effect has probably vanished as the old economic order has vanished. For all developing countries, manufactures rose from only 17.4 percent of commodity exports in 1970 to 64.3 percent by 1994 and this figure is even higher a decade later. Most of the Third World is now labor abundant and natural resource scarce so that they specialize in labor-intensive manufactures. Thus, a fall in the relative price of primary products helps foster its rate of industrialization. The classic image of Third World specialization in primary products has been obsolescing recently, and fast (see Martin 2003; Lindert and Williamson 2003, p. 249). Even sub-Saharan Africa is shifting out of mineral and agricultural exports and in to manufactures, although it only became apparent in the early 1990s. The share of manufactures in total exports in this region was only 12 or 13 percent in 1991, while it was almost 50 percent in 1998 (Martin 2003).

But between the British industrial revolution and the 1970s, a new economic order emerged, one in which the core increasingly specialized in manufactures and the periphery increasingly specialized in primary products. This new economic order had asymmetric volatility and secular growth implications such that the terms of trade exacerbated the growing GDP per capita gap between core and periphery. The impact seems to have been very large.

\section{REFERENCES}

Abramovitz, M., and DaVID, P. A. (1973): «Economic Growth in America: Historical Parables and Realit_Iies».De Economist 121, 3: 251-272.

Baland, J. M., and Francois, P. (2000): «Rent-Seeking and Resource Booms». Journal of Development Economics 61 (2), pp. 527-542.

Blattman, C.; Hwang, J., and Williamson, J. G. (2004): «The Impact of the Terms of Trade on Economic Development in the Periphery, 1870-1939: Volatility and Secular Change». NBER Working Paper 10600, Cambridge, Mass.: National Bureau of Economic Research (June).

Bleaney, M., and Greenway, D. (1993): «Long-Run Trends in the Relative Price of Primary Commodities and in the Terms of Trade of Developing Countries». Oxford Economic Papers 45, pp. 349-363.

- (2001): «The Impact of Terms of Trade and Real Exchange Rate Volatility on Investment and Growth in Sub-Saharan Africa». Journal of Development Economics 65, pp. 491-500.

Boskin, M. J.; Dulberger, E. R.; Gordon, R. J.; Griliches, Z., and Jorgensen, D. W. (1998): «Consumer Prices, the Consumer Price Index, and the Cost of Living». Journal of Economic Perspectives 12, 1 (Winter): 3-26. 
CATÃo, L., and KAPUR, S. (2004): «Missing Link: Volatility and the Debt Intolerance Paradox». Washington, DC: International Monetary Fund, unpublished (January).

Clingingsmith, D., and Williamson, J. G. (2004): «India's De-Industrialization Under British Rule: New Ideas, New Evidence». NBER Working Paper 10586, Cambridge, Mass.: National Bureau of Economic Research (June).

Coatsworth, J. H., and Williamson, J. G. (2004a): «The Roots of Latin American Protectionism: Looking Before the Great Depression», in A. Estevadeordal; D. Rodrik; A. Taylor, and A. Velasco (eds.), FTAA and Beyond: Prospects for Integration in the Americas. Cambridge, Mass.: Harvard University Press.

- (2004b): «Always Protectionist? Latin American Tariffs from Independence to Great Depression». Journal of Latin American Studies 36 (May): pp. 205-232.

Corden, W. M. (1981): «The Exchange Rate, Monetary Policy and North Sea Oil: The Economic Theory of the Squeeze of Tradables». Oxford Economic Papers 33 (Supplement), pp. 23-46.

- (1984): «Booming Sector and Dutch Disease Economics: Survey and Consolidation». Oxford Economic Papers 36 (3), pp. 359-80.

Corden, W. M., and NeARY, J. P. (1982): «Booming Sector and De-Industrialization in a Small Open Economy». Economic Journal 92 (December), pp. 825-848.

Deaton, A., and Miller, R. I. (1996): «International Commodity Prices, Macroeconomic Performance and Politics in Sub-Saharan Africa». Journal of African Economics 5, pp. 99-191, Supplement.

DERCON, S. (2004): Insurance Against Poverty. Oxford: Oxford University Press.

Díaz-Alejandro, C. (1984): «Latin America in the 1930s», in R. Thorp (ed.), Latin America in the 1930s. New York: Macmillan, pp. 17-49.

Fafchamps, F. (2004): Rural Poverty, Risk and Development. Chattenham: Edward Elgar.

Frankenberg, E.; Beegle, K.; Sikoki, B., and Thomas, D. (1999): «Health, Family Planning and Well-being in Indonesia during an Economic Crisis: Early results from the Indonesian Family Life Survey». RAND Labor and Population Program Working Paper Series 99-06, Santa Monica, CA: Rand Corporation.

Gordon, R. J. (1990): The Measurement of Durable Goods Prices. Chicago: University of Chicago Press.

— (1993): «American Economic Growth: One Big Wave?». Economics Department, Northwestern University.

- (2000): «Does the "New Economy" Measure Up to the Great Inventions of the Past?». NBER WP 7833, Cambridge, Mass.: National Bureau of Economic Research.

GREGORY, R. (1976): «Some Implications of the Growth of the Mineral Sector». Australian Journal of Agricultural Economics 20 (2), pp. 71-91.

GrILli, E. R., and Yang, M. C. (1988): «Primary Commodity Prices, Manufactured Goods Prices, and the Terms of Trade of Developing Countries: What the Long Run Shows». World Bank Economic Review 2, pp. 1-48.

Hadass, Y., and Williamson, J. G. (2003): «Terms of Trade Shocks and Economic Performance 1870-1940: Prebisch and Singer Revisited». Economic Development and Cultural Change 51 (April), pp. 629-656.

Hanson, J. R. (1980): Trade in Transition: Exports from the Third World 1840-1900. New York: Academic Press. 
IssawI, C. (1988): The Fertile Crescent 1800-1914: A Documentary Economic History. New York: Oxford University Press.

JACOBY, H. G., and Skoufias, E. (1997): «Risk, Financial Markets, and Human Capital in a Developing Country». Review of Economic Studies 64 (July), pp. 311-335.

Jensen, R. (2000): «Agricultural Volatility and Investments in Children». American Economic Review 90 (May), pp. 399-404.

Kose, M. A., and ReIzman, R. (2001): «Trade Shocks and Macroeconomic Fluctuations in Africa». Journal of Development Economics 65 (1), pp. 55-80.

KraVIS, I. B., and LIPSEY, R. E. (1971): Price Competitiveness in World Trade. New York: National Bureau of Economic Research.

- (1992): «Sources of Competitiveness of the United States and of its Multinational Firms». Review of Economics and Statistics LXIV, 2 (May), pp. 193-201.

Krueger, A. O. (1974): «The Political Economy of the Rent-Seeking Society». American Economic Review 64 (June), pp. 291-323.

LEWIS, W. A. (1954): «Economic Development with Unlimited Supplies of Labour». Manchester School of Economic and Social Studies 22 (May), pp. 139-191.

- (1978): The Evolution of the International Economic Order. Princeton, NJ: Princeton University Press.

Lindert, P. H., and Williamson, J. G. (2003): «Does Globalization Make the World More Unequal?», in M. Bordo; A. M. Taylor, and J. G. Williamson (eds.), Globalization in Historical Perspective. Chicago: University of Chicago Press, pp. 227-271.

LIPSEY, R. E. (1994): «Quality Change and Other Influences on Measures of Export Prices of Manufactured Goods and the Terms of Trade between Primary Products and Manufactures». NBER Working Paper 4671, Cambridge, Mass.: National Bureau of Economic Research.

LiPSEY, R. E.; Molinari, L., and Kravis, I. B. (1991): «Measures of Prices and Price Competitiveness in International Trade in Manufactured Goods», in P. Hooper, and J. David Richardson (eds.), International Economic Transactions: Issues in Measurement and Empirical Research. Chicago: University of Chicago Press.

Martin, W. (2003): «Developing Countries' Changing Participation in World Trade». World Bank Research Observer 18 (20), pp. 187-203.

MendozA, E. (1997): «Terms of Trade Uncertainty and Economic Growth». Journal of Development Economics 54, pp. 323-356.

Mitchell, B. R., and Deane, P. (1962): Abstract of British Historical Statistics. Cambridge: Cambridge University Press.

Mohammed, S. S., and Williamson, J. G. (2004): «Freight Rates and Productivity Gains in British Tramp Shipping 1869-1950». Explorations in Economic History 41 (April), pp. 172-203.

MuRPhy, K.; Vishny, R., and ShleIfer, A. (1989): «Industrialization and the Big Push». Journal of Political Economy 97, pp. 1003-1026.

O'Rourke, K. H., and Williamson, J. G. (1999): Globalization and History. Cambridge, Mass.: Cambridge University Press.

Prebisch, R. (1950): The Economic Development of Latin America and Its Principal Problems. New York: United Nations Economic Commission for Latin America.

PritchetT, L. (1997): «Divergence, Big Time». Journal of Economic Perspectives 11 (3), pp. 3-17. 
RAMEY, G., and RAMEY, V. A. (1995): «Cross-country Evidence on the Link between Volatility and Growth». NBER Working Paper 4959, Cambridge, Mass.: National Bureau of Economic Research.

Rosenweig, M. R., and Wolpin, K. I. (1993): «Credit Market Constraints, Consumption Smoothing, and the Accumulation of Durable Production Assets in Low Income Countries: Investments in Bullocks in India». Journal of Political Economy 101 (2), pp. 223-244.

SACHS, J., and WARNER, A. (2001): «The Curse of Natural Resources». European Economic Review 45 (May), pp. 827-838.

SpraOS, J. (1980): «The Statistical Debate on the Net Barter Terms of Trade between Primary Commodities and Manufactures». Economic Journal 90, pp. 107-128.

SINGER, H. W. (1950): «The Distribution of Gains between Investing and Borrowing Countries». American Economic Review 40, pp. 473-485.

Thomas, D.; Beegle, K.; Frankenberg, E.; Sikoki, B.; Strauss, J., and Teruel, G. (2004): «Education in a Crisis». Journal of Development Economics 74 (June), pp. 5385.

Tornell, A., and Lane, P. R. (1999): «The Voracity Effect». American Economic Review 89 (1), pp. 22-46.

Tornell, A., and Velasco, A. (1992): «The Tragedy of the Commons and Economic Growth: Why Does Capital Flow from Poor to Rich Countries?». Journal of Political Economy 100, pp. 1208-1231.

Williamson, J. G. (2002): «Land, Labor and Globalization in the Third World 18701940». Journal of Economic History 62 (1), pp. 55-85.

- (2005a): Globalization and the Poor Periphery before the Modern Era: The Ohlin Lectures. Cambridge, Mass.: MIT Press.

- (2005b): «Explaining World Tariffs 1870-1938». Stolper-Samuelson, Strategic Tariffs and State Revenues», in R. Findlay; R. Henriksson; H. Lindgren, and M. Lundahl (eds.), Eli Heckscher, 1879-1952: A Celebratory Symposium. Cambridge, Mass.: MIT Press. 
GLOBALIZATION, DE-INDUSTRIALIZATION AND UNDERDEVELOPMENT IN THE THIRD...

\section{APPENDIX}

\section{ADJUSTING TERMS OF TRADE TRENDS FOR QUALITY CHANGE IN MANUFACTURES}

John Spraos (1980) calculated that the price of primary products relative to manufactures fell at about 0.5 percent per annum between the $1870 \mathrm{~s}$ and just before World War II. Enzo Grilli and Maw Cheng Yang (1988) reached the same conclusion for the period between 1900 and 1986, a 0.5 percent per annum deterioration. To the extent that manufactured goods undergo quality improvements while primary products do not, the measured deterioration in the relative price of primary products between 1870 and 1940 is overstated. And while the secular increase in the terms of trade facing primary producers in the poor periphery before 1870 is certainly impressive, how much bigger would the measured increase have been were quality improvements in manufactures included? We have no such estimates for the $19^{\text {th }}$ century, but we do have them for the $20^{\text {th }}$ century. This section of the appendix reports what happens when the latter estimates are used to explore their potential impact on the former.

There have been very few attempts to gauge how product quality changes influence export and import prices, and thus the terms of trade, although there have been quite a few attempts to correct domestic prices for quality change. Most of the latter have been for post-war United States (Gordon 1990; Boskin et al. 1998) and hedonic techniques have been preferred by most investigators. Robert Lipsey and his collaborators have used the estimated impact of US product quality change on traded goods prices (Kravis and Lipsey 1971, 1992; Lipsey, Molinari, and Kravis 1991; Lipsey 1994). For the period 1953 to 1991, they report two findings that are especially relevant to any assessment of the long run impact of terms of trade on core relative to periphery.

First, «these quality adjustments are much too gradual to offset the large shortterm or medium-term cycles in terms of trade» (Lipsey 1994, p. 19). This is an important finding since it implies that volatility measures of the terms of trade 1870-1940 will not be affected by the omission of quality adjustments.

Second, however, secular movements in the pre-1940 terms of trade are likely to be profoundly affected since the «average declines in the [quality] adjusted indexes relative to the unadjusted ones for [US] exports to the world ... are ... more than a half percent per year for all manufacturers ...» (Lipsey 1994, p. 18). Thus, the fall in the terms of trade facing primary product exporters 19001986 estimated at 0.5 percent per annum would have been completely offset if the 0.5 percent per annum quality change for manufactures during the second half of the $20^{\text {th }}$ century had also applied to the first half. What appeared to 
Prebisch and Singer to be a spectacular fall in the relative price of primary products up to 1940 may have been an illusion created by mis-measurement. Furthermore, the rise in the terms of trade facing primary product exporters 1810-1870 must be understated to the extent that this post-World War II experience also applied to the pre-1870 period, although perhaps not with as much drama.

Since the rate of productivity advance was faster in the $20^{\text {th }}$ century than it was in the 19th century, there is little reason to believe that the same 0.5 percent per annum adjustment would apply to the 1810-1870 terms of trade boom facing the periphery. But suppose that the rate of quality improvement in traded manufactures was highly correlated with the rate of productivity growth in manufacturing. If so, a quality adjustment would still be necessary for 1810-1870, but it would be a much smaller adjustment than for 1953-1991. We have a fair idea of how much smaller.

The best long run estimates of total factor productivity growth (TFPG) or multi-factor productivity growth (MFPG) are for the United States and they also have the advantage of being estimated separately for manufacturing. These figures and their implications for guesses about the rate of quality change on traded manufactures are reported in Table A-1:

TABLE A-1

ESTIMATED PRODUCTIVITY GROWTH AND QUALITY

CHANGE IN MANUFACTURES: THE UNITED STATES 1800-1990

(Percentage rates per annum)

\begin{tabular}{|c|c|c|c|c|c|}
\hline Epoch & $\begin{array}{c}\text { TFPG } \\
\text { Economy }\end{array}$ & Epoch & $\begin{array}{c}\text { MFPG } \\
\text { Manufactures }\end{array}$ & $\begin{array}{c}\text { MFPG } \\
\text { Economy }\end{array}$ & $\begin{array}{c}\text { Estimated } \\
\text { Quality } \\
\text { Change in } \\
\text { Manufactures }\end{array}$ \\
\hline $1800-1855 \ldots \ldots \ldots \ldots . . . .$. & 0.3 & $1800-1870$ & $(0.46)$ & $(0.28)$ & 0.09 \\
\hline $1855-1905 \ldots \ldots \ldots \ldots . .$. & 0.5 & $1870-1913$ & 0.77 & 0.46 & 0.15 \\
\hline $1905-1927 \ldots \ldots \ldots \ldots . . .$. & 1.5 & 1913-1964 & 1.60 & 1.95 & 0.63 \\
\hline 1927-1967............. & 1.9 & 1964-1990 & 0.62 & 1.55 & 0.50 \\
\hline
\end{tabular}

Sources and Notes: TFPG Economy from Abramovitz and David (1973, Table 1, p. 254). MFPG Economy from Gordon (2000, Table 1). Numbers in parentheses interpolated from the first column. MFPG Manufacturing from Gordon (1993, Table H). Numbers in parentheses interpolated from first column. The estimated quality change for 1964-1990 uses Lipsey's 0.50 estimate for 1953-1991; the other entries are assumed to follow the same trend as the MFPG for manufacturing.

To account for these estimated quality improvements in imported manufactured goods, Table A-1 implies that the per annum rate of change in the terms of trade facing poor primary product exporters should be raised by: 1810-1870 0.09; 
1870-1913 0.15; 1913-1939 0.63; and 1870-1939 0.33. These estimates are used in Figure 1 and in the text discussion.

\section{FACTORING OUT THE IMPACT OF TERMS OF TRADE VOLATILITY ON GROWTH IN THE POOR PERIPHERY 1815-1870}

There are several options for decomposing terms of trade movements into trend and volatility. One can employ the terms of trade growth rate and the standard deviation of the growth rate. Yet, the growth rate of the terms of trade over, say, a decade will be overstated if there is a positive shock in the tenth year, and understated if there is a negative shock. More volatile countries will thus be measured with less accuracy, leading to systematic measurement error. In addition, a structural break or a discrete change in the rate of growth will register as both a change in trend and a change in volatility, potentially confusing the effects. Furthermore, persistent shocks away from trend will result in a lower measure of volatility than a shock that returns to trend the following year. Shocks that persist for more than a year before returning to trend will register as volatility, since they remain deviations from measured trend. The standard deviation of the growth rate of the terms of trade, on the other hand, will instead register only the initial shock and its eventual return to trend as volatility. The more gradual and consistent the return to trend, the lower the volatility measure, and so shocks that die out slowly will register as less volatile, even though the distortion may be greater.

Since the goal is to use measures of trend and volatility that do not relate in a systematic way to one another and that minimize the measurement error in the trend, a practical solution is to use a filter that produces a smooth trend and stationary deviations. The Hodrick-Prescott (HP) filter is a common choice, and Chris Blattman, Jason Hwang and myself (2004) have employed it in past work ${ }^{15}$.

Terms of trade time series data have been collected for the following seven regions: Egypt, India, Indonesia, Latin America, the Mideast, Spain and the Ottoman Empire (Turkey) ${ }^{16}$. To summarize the discussion above, volatility is measured here as the standard deviation of departures from a trend calculated

15 The smoothing parameter in the HP filter is set at 300, which implies a relatively slow-changing trend. A more quickly changing trend (such as that achieved with a smoothing parameter of 100 or lower) does not materially affect the results.

${ }^{16}$ The sources of the pre-1870 price data for exports $(\mathrm{Px})$, imports $(\mathrm{Pm})$ and thus for the net barter terms of trade $(\mathrm{Px} / \mathrm{Pm})$ for Indonesia, India, Latin America, Turkey and Egypt can be found in Clingingsmith and Williamson (2004). The Px/Pm data for the United Kingdom are from Brian Mitchell and Phyllis Deane (1962, p. 331). The Mideast Px/Pm data are composed of an unweighted average of Aleppo, Beirut and Iraq (Issawi 1988, p. 148-50). The Px/Pm data for Spain are from ongoing research by Leandro Prados. 
using the Hodrick-Prescott filter. Bigger standard deviations imply, of course, greater volatility. Here is what we find:

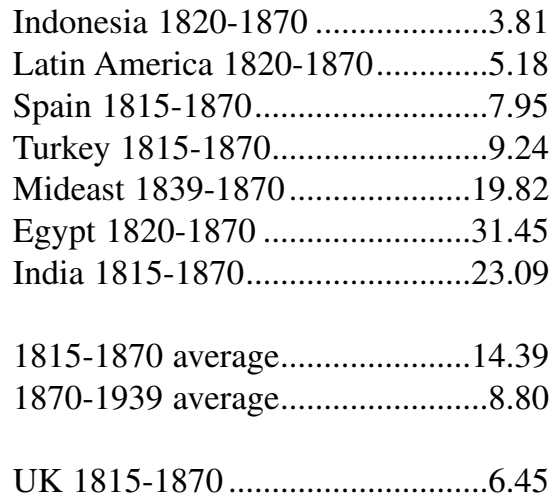

The pre-1870 terms of trade volatility in the poor periphery was much greater than it was afterwards. What is more stunning, however, are the differences between these regions, all of which were dictated by natural endowment and commodity specialization. Indonesia and Latin America had very stable terms of trade. Egypt, India, and the Mideast, on the other hand, had immense volatility. Spain and Turkey lay somewhere in between with volatility figures closer to the 18701939 average.

The text applies these volatility measures for the decomposition analysis. 